\title{
Challenging Neoliberalism: Making Economic and Social Rights Matter in the Peacebuilding Agenda
}

\author{
Amanda Cahill-Ripley
}

\section{INTRODUCTION}

Despite the rise in the legal recognition of economic and social rights throughout the world, there are contexts in which these rights are purposely rendered invisible by the ideology and policy frameworks of neoliberalism (MacNaughton and Frey, Chapter 1 in this volume). One such context is the global peacebuilding agenda. Peacebuilding programs, including transitional justice mechanisms, have traditionally ignored or marginalized economic and social rights in favor of addressing civil and political rights. Given the strong evidence to suggest that economic and social rights violations act as root causes of conflict and can also constitute gross and systematic human rights violations under international criminal law, this may seem surprising. However, when the tension between neoliberalism and building peace is explored, the continuing invisibility of such rights is foreseeable.

This chapter provides an overview of the current dominant peacebuilding paradigm, noting both its achievements and existing critiques of this approach. It then examines the reasons why economic, social, and cultural rights are important for building and sustaining peace, before offering a critical appraisal of the neoliberal model, including an identification of the inherent tension between the ideology of neoliberalism and the aims of positive sustainable peace. Further, the chapter scrutinizes the neoliberal model to establish the reasons why it fails to address economic, social, and cultural rights sufficiently. Focusing on the need for people-centered policy and the concept of human security, the chapter then explores alternative approaches to peacebuilding. It then argues for a new model of peacebuilding: The "human security plus approach" and outlines how such a model can be operationalized. The central contention is that a refocusing of priorities upon the human security of people, rather than a focus on national security and market-driven 
reconstruction, can confront the neoliberal ideology and policy framework that underlies (and undermines) peacebuilding. In turn, this human security plus approach should support claims for social justice in a transitional and postconflict context. Finally, the chapter offers some conclusions as to how to ensure that economic, social, and cultural rights not only matter within the peacebuilding agenda but also are considered fundamental to sustaining peace.

\section{THE DOMINANT PEACEBUILDING PARADIGM: NEOLIBERAL PEACEBUILDING}

The current prevailing approach to peacebuilding is based upon a liberal agenda, which emphasizes democracy, rule of law, free markets, and institution building (Mac Ginty 2010, 393; Paris 1997, 56; Richmond 2007, 462). The positive aspects of this model are severalfold. They include successful missions to tackle and end direct and open violent conflict; efforts to encourage and enshrine the enjoyment of civil and political rights through the establishment of constitutional and political frameworks and democratic institutions, including National Human Rights Institutions; and economic development and postconflict reconstruction. Consequently, this model of peacebuilding is often successful in reducing the absolute numbers of conflicts on the ground, containing conflicts and maintaining regional and or international stability. Some would argue that this is the limit of what peacebuilding can achieve. As such, the current dominant peacebuilding paradigm can be viewed as a success if measured against the definition of peace as the absence of direct violent conflict. This is known as "negative peace" (Galtung 1969, 167).

Although such an approach has resulted in some very positive outcomes, where this [neo]liberal peacebuilding framework has been successful in ending open conflict (Paris 2010, 353), evidence suggests that in terms of sustaining peace (and as such addressing underlying or covert structural violence), the record of using such a model is questionable (Newman 2011, 1739). Paris notes, "The record of [liberal] peacebuilding has indeed been disappointing. Efforts to promote liberal democratic governing systems and market-oriented economic growth - both core elements of the prevailing liberal peacebuilding model - have been more difficult and unpredictable than initially expected, in some cases producing destabilising side effects" (Paris 2010, 337). In addition, scholars, practitioners, and local stakeholders have criticized this model as paying "insufficient attention to basic and everyday human needs" (Newman 2011, 1737). Accordingly, there have been numerous critiques of this liberal peacebuilding paradigm, for example the work of Richmond (2007, 2013, 2014); 
Mac Ginty (2010); Brett and Malagon (2013); and Newman (2011) to name a few. Further, the intersection between conflict transformation and human rights has been explored by scholars such as Parlevliet (2018) and Schirch (2006). However, very little has been written critically examining the specific nexus between economic, social, and cultural rights and peacebuilding. Notable exceptions include Cahill-Ripley (2016) and material relating primarily to the field of transitional justice, for example Sharp (2014), Arbour (2007), Schmid (2015), Laplante (2008) and Cahill-Ripley (2014). Consequently, this chapter adds to the critiques of liberal peacebuilding by developing a new dimension of a human rights perspective, focusing on economic, social, and cultural rights, and examining the impact of the neoliberal dominance of the peacebuilding agenda on the enjoyment of these rights in this context.

As Paris argues, despite the numerous shortcomings of the liberal peacebuilding agenda, many missions have "done more good than harm," and abandoning the liberal peacebuilding project "would be tantamount to abandoning tens of millions of people to lawlessness, predation, disease and fear" $(2010,338)$. As such, this chapter argues for a critical reevaluation of the neoliberal peacebuilding agenda and the development of a new approach that emphasizes and incorporates economic, social, and cultural rights (alongside civil and political rights) into peacebuilding, but does not discard the entire peacebuilding project.

\section{WHY ECONOMIC AND SOCIAL RIGHTS ARE IMPORTANT FOR} PEACEBUILDING: TACKLING DIRECT AND STRUCTURAL VIOLENCE

Economic and social rights are important for building peace because violations of economic and social rights are often root causes of conflict or act as underlying grievances contributing to conflict (Cahill-Ripley 2014, 2016; International Council on Human Rights Policy 2006, 101; Laplante 2008, 331 and 333). Moreover, such violations can constitute gross and systematic violations of human rights that can be considered crimes under international criminal law (Schmid 2015), for example, the burning and destruction of homes and crops; the poisoning of water; forced evictions; deliberately induced starvation and displacement leading to lack of housing, water, and food, subsequent ill health and disease, lack of education and employment, and in the worst cases human deaths (Cahill-Ripley 2014, 184). Such violations can be deemed within the mandate of various transitional justice mechanisms, such as international criminal courts and tribunals, and truth and reconciliation commissions, and may be more widespread and systematic than civil and political rights violations. 
In the conflict in Timor-Leste, for example, the mandate of the Commission for Reception, Truth and Reconciliation (CAVR) provided that the CAVR would enquire into "Violations of a broad range of human rights standards" including rights and freedoms within, inter alia, the International Covenant on Economic, Social and Cultural Rights (ICESCR) 1966 (The Commission for Reception, Truth and Reconciliation in Timor-Leste 2005a, part 2, , para. 15). The CAVR noted that far more people were affected by economic and social rights violations than by civil and political rights violations (The Commission for Reception, Truth and Reconciliation in Timor-Leste 2005b, 74 and The Commission for Reception, Truth and Reconciliation in Timor-Leste 2005 chapter 7.9). The deliberate policy of forced displacement led to famine, "hunger and deprivation of the means of making a livelihood" as "food crops, livestock, housing, agricultural implements and land" were all destroyed (The Commission for Reception, Truth and Reconciliation in Timor-Leste 2005d, chapter 7.3 , section $7(7.3 .7)$, para. 503(5)). This displacement of people from their villages, farms, and traditional settlements resulted in severe violations of the rights to food, health, housing, and education, self-determination of resources, and freedom of movement (The Commission for Reception, Truth and Reconciliation in Timor-Leste 2005b, 74; The Commission for Reception, Truth and Reconciliation in Timor-Leste 2005c chapter 7.9). For others it resulted in death. In its detailed report, the CAVR found that, "Death was caused by famine, famine-related diseases, vulnerability to sickness from hunger, fear or exhaustion and a lack of access to medical care. It is likely that more people died from the effects of displacement than from any other violation, while the actual number of deaths is incalculable" (The Commission for Reception, Truth and Reconciliation in Timor-Leste 2005d, chapter 7.3.7, para. 503(4)). Conservative estimates put the number of deaths due to hunger and illness caused specifically by the conflict (1975-99) at 75,000-86,500 people (Silva and Ball 2006, 14-15).

These economic and social rights violations were attributable to direct violence of high-intensity conflict. Significantly however, many economic and social rights violations result from protracted structural violence, which can be further exacerbated by conflict. Structural violence exists when the structures of the state support the unequal distribution of power (and agency), which is reinforced through unequal distribution of resources (Cahill-Ripley 2014, 191). Thus, structural violence based upon this "unequal distribution of power then systematically disadvantages those who do not hold as much if any power at all" (Ho 2007, 4). Examples of such structural violence can include racial inequality, poverty, and institutionalized discrimination. What is more, the link between structural violence and violations of economic and social rights 
is clear. Ho notes that " $[\mathrm{w}]$ hen economic and social structures conspire to limit one's agency to the extent that fundamental human needs cannot be met, then structural violence becomes a structural violation of human rights" $(2007,15)$.

Clearly, structural violence can constitute economic and social rights violations and can cause further violations. For example, the Kenyan Truth, Justice and Reconciliation Commission noted that "economic marginalization of communities and exploitation of economic resources" contributed to the conflict in Kenya (Kenyan Truth, Justice and Reconciliation Commission $2013,48-53$ ), as did "historical land injustices as manifested by the presence of IDPs [internally displaced people], the poor and other disadvantaged groups and gender and generational inequalities characterized by skewed allocation of opportunities and resources" (Kenya Human Rights Commission, The Kenyan Section Of The International Commission Of Jurists And International Centre For Policy And Conflict 2010, 77). This example illustrates the nexus between structural violence, conflict, and socioeconomic rights. However, often such violations of economic and social rights are presented as background context - inevitable conditions due to lack of development or poverty (Cahill-Ripley 2014, 184). The neoliberal framework for addressing these "conditions" is through the incorporation of policies such as the World Bank's Poverty Reduction Strategies and the UN Sustainable Development Goals. Yet these strategies are confined within the neoliberal agenda and do not extend to redistribution of wealth. For example, "according to the FAO enough food is produced to feed the whole world population, [...] the equivalent of 2,700 calories each per day" (Ziegler et al. 2011, 1-3). However, the relevant sustainable development goal focuses on "ending hunger and achieving food security” (UN General Assembly 2015, Sustainable Development Goal 2, Target 2.1) without acknowledging that inequality is at the root of hunger, rather than food shortages, or that "the schizophrenia of the UN system and state policies" act to undermine this goal (Ziegler et al. 2011, 1-3).

The underlying endorsement of inequality, as necessary to the success of capitalism, is rendered invisible by efforts to address conditions that actually constitute human rights violations as simply the inevitable consequences of the world system. Similarly, economic and social rights have been rendered invisible by this agenda as they offer a framework that illuminates inequality, discrimination, and the structural violence that lies beneath them. The consequence for peacebuilding efforts is evident. If there is no attempt to address these structural inequalities in societies, then there is a risk that violent conflict will resurface despite efforts to address classic neoliberal concerns such 
as civil and political rights, economic development (based upon neoliberal economic reforms), and building democratic institutions and processes.

As such, there is a question to be answered as to how the peacebuilding agenda can address violations of economic and social rights, both those that have taken place as a direct result of violent conflict, but also systematic and structural violations of economic and social rights that act as an ongoing source of injustice. Laplante notes, "presenting socioeconomic root causes of conflict as historical context leaves policy change to the discretion of political leaders, while presenting them as rights violations makes redress and reform a political imperative" $(2008,341)$. Consequently, ignoring violations of such rights is a risk to the effectiveness of justice mechanisms during transition and to wider efforts to achieve a sustainable peace.

\section{THE LIMITS OF THE CURRENT PEACEBUILDING AGENDA}

The current failure to deal with economic and social rights within the peacebuilding agenda is not accidental. Rather, it is a deliberate result of the marginalization of basic human needs or their omission from the neoliberal peacebuilding agenda coupled with the requirement inherent in the neoliberal system to maintain inequality and competition as a basis of the economic system. As Richmond notes, "Neoliberalism represents the ideological belief that inequality is not a political or moral issue, nor does it lead to conflict, but instead it promotes competition, innovation and entrepreneurship, even in post-conflict and development environments" (2014, 450). Conversely, empirical evidence clearly shows that inequality drives conflict and "weakens the link between civil society, human rights and a rule of law, democracy, development and peacemaking" (Richmond 2014, 450). Hence, the contradiction between neoliberalism and sustaining peace is inevitable.

Moreover, as inequality is preserved, ideas of solidarity, equality, and social justice have been marginalized. "Broader rights frames, including socio-economic and collective rights, have systematically been side-lined from peace settlements and from the concurrent state-building enterprises of Liberal Peace politics, as well as from accompanying TJMs [transitional justice mechanisms]" (Brett and Malagon 2013, 258). If economic and social concerns are addressed, it is usually as an element of social policy or development outside of a rights-based framework, rather than through a human rights framework that is integral to the conflict transformation process. Economic, social, and cultural rights are reduced to the status of policy aims or ideals. At best, they are viewed as secondary rights - general aims to be achieved progressively as the ideal standard (Arbour 2007, 11; Sharp 2012, 780, 797). 
At worst, they are rendered completely invisible by the use of a restricted human rights framework that fails to recognize such rights as legal rights. Instead, neoliberal peacebuilding utilizes a limited human rights framework (Mac Ginty 2010, 391), recognizing only civil and political rights. The need to address basic human needs through the protection and promotion of economic, social, and cultural rights has been omitted from or at best marginalized in the peacebuilding process.

As noted previously, the prevailing motivation that underlies state and international organization participation in peacebuilding initiatives is the maintenance of "international security" and containment of conflict (in part so as not to damage the market). Peacebuilding is framed as a necessary requirement for stability of the country, neighboring states, and the wider region, as well as for global security. While this approach prioritizes effective governance and results in much-needed humanitarian assistance, resources for development, and capacity building, it also emphasizes conflict containment rather than conflict resolution and peacebuilding. The priority is minimizing armed conflict between actors and states, and the interests of those intervening can take precedence over addressing the root causes of the conflict. For example, local demands for justice regarding economic and social rights violations in relation to displacement from housing or inadequate access to food and water, or tackling continuing discrimination, can be deprioritized or even excluded in favor of externally driven top-down processes that focus on dealing with elites and existing leaders, building state-level democratic institutions and establishing stable government to contain conflict and enable trade. This hampers community-driven peacebuilding with alternative or conflicting priorities and agendas for peace. Hence, the peacebuilding agenda becomes externally driven - often a donor-led agenda (Newman 2011, 1741).

Moreover, as a state does not exist in isolation but rather exists within the global international community of states, the influence of external actors upon transitional or postconflict reconstruction, in particular regarding resources, is inevitable and often significant. Because of the limited national resources that are available in a state that is in transition or postconflict, the role of international actors in institution building, development, and reconstruction is crucial. However, international assistance is usually accompanied by various international agendas and specific conditions set by the organization(s) or state(s) offering their assistance. Notable in the current climate are the policies of the international financial institutions (IFIs), such as the IMF and World Bank. "International institutions such as the World Bank and the International Monetary Fund often push for market-driven reforms which may not take adequate account of the post-agreement need for large-scale 
public spending" (International Council on Human Rights Policy 2006, 101). Even bilateral development partners "frequently operate outside a human rights-based framework or with an idiosyncratic one which reflects the donor's particular interests and priorities" (O'Flaherty 2003, 6o; Skaar and Wiebelhaus-Brahm 2013).

Thus, as noted, the dominance of neoliberalism ensures that many, if not most, peace processes involve transition from violence not just to peace, but also to liberal democracy, which involves economic transition to a liberalized economic model (International Council on Human Rights Policy 2006, 101), whether this is necessarily a good thing or not, and regardless of local priorities for peace and development. The foremost priority within this neoliberal model is the economic development of the state, based upon quantitative statistics as measures of progress. While quantitative data are useful and have a role to play in the overall development of a postconflict state, quantitative statistics can obscure serious problems, inter alia, inequality and /or discrimination on the grounds of gender, ethnicity, or race, or rural/urban discrepancies. The decisions as to which data to gather, coupled with the lack of disaggregated data, ensures that such inequalities can be masked by statistics that substantiate overall economic progress.

Moreover, this heavy reliance on top-down promotion of democracy and market-based economic reforms reinforces existing inequality and can exacerbate social grievances. Inappropriate market liberalization, including privatization or public spending cuts, in transitional societies can threaten the realization of fundamental economic and social rights implemented through broader peacebuilding goals, such as public service delivery (Newman 2011, 1744). Ultimately, as Richmond argues, "neoliberalism exposes the post-conflict individual, community and state to the full force of a market framework in which they are unable to compete, and often unable to access" (2014, 453).

Such an approach pays "insufficient attention to basic and everyday human needs" (Newman 2011, 1737). The significant emphasis on free trade and market-based economic reforms that are key to neoliberal peacebuilding can also have a negative impact on the effectiveness of peacebuilding processes, as they are often externally driven, top-down processes that tend to focus on dealing with elites and existing leaders, thus often ignoring local voices for peace (Mac Ginty 2010, 403). This is especially likely where local priorities may be different or even conflict with the donor-led agenda (Newman 2011, 1741), such as instances where grassroots communities view the realization of economic and social rights as essential for sustainable peace. In such situations, peace is often built on "force rather than consent, [and] conditionality, and fails to recognise local cultural norms and traditions" (Richmond 2009, 563). 
Another problem is the "institutionalist" approach central to the prevailing model, which focuses on institution building and institutional reform as end goals in themselves, (Richmond 2007,461 ), rather than seeing the end goal as the improvement of the lives of people, including the protection and promotion of all human rights. This institutionalist view assumes that with operational democratic state institutions and free market conditions, the objectives of peacebuilding will be generated (Newman 2011, 1743). Once key institutions are formally established, "development will move forward and serve peace" (Newman 2011, 1743). However, these "shells of institutions" (Thiessen 2011, 121) do not deliver democracy but rather largely benefit existing elites. Moreover, democracy does not equal peace. In fact, societies in transition to democracy are more likely to experience conflict and destabilization. This is especially true of societies with existing divisions, social inequality and lack of human rights enjoyment (Newman 2011, 1743).

In sum, the neoliberal approach is often successful in reducing the absolute numbers of conflicts on the ground and in ending open conflict. However, evidence suggests that in terms of sustaining peace, the record is uncertain. The consequence of this approach is a fragile peace, weak institutions, social unrest, segregation, discrimination, political volatility or stagnation, and the threat of insecurity. That is not to argue that negative peacebuilding is not necessary; it is clearly a prerequisite for more transformative peacebuilding. However, such a framework is "ineffective in precipitating structural transformation and preventing recurrence of conflict" (Brett and Malagon 2013, 258). Overall, the dominant neoliberal world system has permeated the theory and practice of peacebuilding, resulting in an approach that fails to address social justice concerns and to tackle the underlying root causes of conflict and often does not recognize structural violence as a driver of conflict (Schirch 2006, 69). As such, economic, social, and cultural rights violations, inequality, discrimination, and exclusion can remain obstacles to sustainable peace. When the "peace dividend is not equitably spread" (Newman 2011, 1745), the seeds of unrest remain and reconciliation is difficult. The central question then is: Do economic and social rights harbor "transformative potential" (MacNaughton and Frey, Chapter 1 in this volume) to challenge this hegemonic model within this context?

\section{CHALLENGING THE NEOLIBERAL PEACEBUILDING AGENDA}

The dominance of neoliberalism can clearly be seen in the current peacebuilding agenda, which is market-focused rather than people-focused. Scholars such as Schirch (2006) and Lambourne (2004), however, have 
proposed alternative approaches with a more ambitious vision of peacebuilding as transformative in nature. As Schirch explains,

Peacebuilding prevents, reduces, transforms, and helps people to recover from violence in all forms, while at the same time empowering peoples to foster relationships at all levels to create structural justice...Peacebuilding pursues a just peace ... [which] recognises that justice pursued violently contributes to further injustice and human rights violations, and that peace without justice is unlikely to be sustainable or to meet peoples basic needs. Just peace exists where a sustainable set of structures and processes allows people to meet their basic human needs and protects their human rights with an absence of either direct or structural violence. Peacebuilding recognises the importance of efforts to reduce direct violence while pursuing a deeper transformation of structures, paradigms, cultures and values over a longer time frame (Schirch 2006, 64).

In line with Schirch, this chapter proposes a specific model addressing structural violence and challenging the pervasiveness of neoliberalism within the dominant peacebuilding agenda. The aim of this model is to refocus on people by engaging human rights and the related concept of human security. Human security is an emancipatory model focused on meeting basic human needs and local empowerment (Richmond 2007, 462; Thiessen 2011, 126). A human-security approach to peacebuilding has evolved from basic humanneeds theory within the field of conflict transformation. Championed by John Burton in 1979 (see also Burton 1990), the idea that there exist basic human needs "whose fulfilment is a necessary condition of human life and development" is a compelling and enduring theory that has been examined and adopted in various fields of study including philosophy (for example, Aristotle differentiated between human needs and wants), social psychology (most famously in Maslow's hierarchy of needs) and problem-solving approaches within conflict resolution (Avruch and Mitchell 2013, 5).

Despite a lack of consensus as to the content and the universality of these basic human needs (Avruch and Mitchell 2013, 230-5), the concept was also central to international development theory. During the 1970 and up to the mid-198os, progressive thinking around development led to the idea that development should not be defined in a pure economic sense but rather should be more broadly conceptualized as encompassing human development based on fulfillment of "fundamental human needs" (Avruch and Mitchell 2013, 9).

This idea of the relationship between basic human needs, poverty, and human development was adopted by both the UN and the ILO. However, it was soon to be marginalized, owing to the rise of neoliberalism and a return to 
economic orthodoxy in the 1980s (Avruch and Mitchell 2013). As Avruch and Mitchell note, "The era of structural adjustment as conditions for the IMF and World Bank loans, and neoliberal monetarist policies generally, buried the discourse of basic human needs in approaches to development" $(2013,10)$. Despite this marginalization, it is true today that the idea of basic human needs in some form continues to be a central idea reflected in discourses on development, conflict transformation, human security, and human rights (Avruch and Mitchell 2013, 233), and recognition of the nexus of sustainable development, peace and security, and human rights is now enjoying a renaissance.

Significantly, human security as a concept is particularly apt in the context of peacebuilding as conflict increases human insecurity. As Newman notes, "Human insecurity - deprivation, alienation and exclusion - is a direct threat to peacebuilding processes and objectives, since these undermine the legitimacy of peacebuilding and fuel the underlying sources of conflict" (2011, 1740). In addition, the use of human security as an idea is useful as a bridging concept between human rights, peacebuilding, and development practitioners, as it is utilized and understood by all fields and highlights the commonalities in objectives through its focus on people, not states. It also highlights the collective aspect of human rights, focusing on the needs and security of communities and groups rather than just individuals. As such, the human security - human rights nexus can "better address...issues of structural vulnerability in an interrelated and contextualized manner” (Estrada-Tanck 2016, 9).

\section{A HUMAN SECURITY PLUS APPROACH}

It remains the case that "the manner in which human security might be applied to contemporary challenges both theoretical and practical remains underexplored" (Newman 2011, 1748; Richmond 2013, 205). One way in which human security can be employed is through the use of human rights as a framework for peacebuilding. A human rights approach to peacebuilding works to improve human security for all people (Schirch 2006, 65). Some of the human needs identified by Burton (and others, for example, Galtung 1990, 304), such as safety and security of the person, welfare or sufficiency needs, freedom needs, and distributive justice in relation to resources, can be easily translated into human rights, in particular, basic rights and consequently economic, social, and cultural rights as enshrined in international law. The link between Shue's basic rights to security, subsistence and liberty, and economic and social rights is clear when the substantive content of the ICESCR and other international human rights law provisions are examined (Shue 1996). Schirch argues that "the idea of human security bridges the concepts of human rights and human needs" (2006, 
65). However, it is submitted that the concept of economic and social rights (alongside civil and political rights) transforms human needs and human security into rights, whereby human security becomes a matter of legal entitlement.

"Human security suggests that public policy must be directed above all at enhancing the personal security, welfare and dignity of individuals and communities" (Newman 2011, 1749). A rights-based approach to peacebuilding draws parallels with a human-security approach, but there are significant differences: An inclusive human rights approach, with particular emphasis on economic and social rights, would share these aims, but with the added value of enshrining such aims within the law. Fulfillment of basic needs and the dignity of the human person become a matter of legal entitlement rather than policy aims (which constitute mere aspirations or can be ignored as conflicting with neoliberal objectives). "Needs" language suggests that the individuals can be blamed for not being able to satisfy those needs themselves (reinforced by the neoliberal belief in individual responsibility). It also ensures such individuals are dependent on charitable help to meet those needs (Schirch 2006, 89).

Rights language, on the other hand, is empowering "bringing with it legal tools to enforce and protect" (Schirch 2006, 89). The legal framework of economic, social, and cultural rights demands that there are rights holders and corresponding duty bearers, which clearly challenges the idea that competition and the market can be relied upon to ensure basic needs are met. In this way, an economic and social rights framework takes the human-security approach to peacebuilding a step further. Moreover, it can be employed now to begin challenging and transforming the prevailing liberal peacebuilding agenda that currently exists. It can do so by utilizing existing international human rights law frameworks (and domestic provisions where applicable) and applying the frameworks in an expansive manner. In this way, mobilization and lobbying for economic and social rights can be prioritized, rather than sidelined or ignored in favor of civil and political rights provisions. Newman similarly notes that a human-security approach to peacebuilding, while problematizing and exposing the flaws of the liberal peacebuilding agenda "can be applied within this same context" (Newman 2011, 1753). However, the inclusive human rights-based approach has added value, as it transforms the human-security framework into an approach to peacebuilding founded on and consistent with substantive legal human rights protections.

A further challenge is that framing this approach as a "human rights-based approach" to peacebuilding may be interpreted as maintaining the status $q u o$, that is, falling into the neoliberal interpretation of human rights with a predominant focus on civil and political rights - rather than an approach 
that clearly challenges this agenda and views human rights as indivisible and interdependent (as noted in numerous instruments of international human rights law, for example ICESCR 1966 Preamble; Proclamation of Teheran 1968; UDHR 1948; World Conference on Human Rights 1993). It is evident that if a peacebuilding program is to address the idea of human security as its priority then a holistic approach must be taken to protecting human rights. Human security cannot be achieved through the realization of civil and political rights alone, but requires addressing all human rights. "Economic, social and cultural rights may be implicit in, or constitute the basis for, the realisation of civil and political rights and vice versa" (Mapulanga-Hulston 2002, 32). In a peacebuilding context, for example, people will be unlikely to engage with democratic institutions and postconflict politics, including the right to vote, if their housing is inadequate or their access to education is denied owing to continuation of the discrimination that was a root cause of the conflict. Consequently, without this indivisibility of rights being "operationalized," the underlying sources of unrest and violent conflict can remain.

In light of the previous misleading use of human rights rhetoric in peacebuilding (Schirch 2006, 91) to refer to civil and political rights only, it will be preferable to deem this new peacebuilding agenda as "Human Security Plus," noting the emphasis on economic and social rights as a priority for human security and a prerequisite for the realization of all human rights, democracy, and the rule of law.

A human-security approach emphasizes addressing the root causes of conflict and resolving them, rather than focusing on negative peace and containment (Newman 2011, 1750). This means such an approach can address structural violence, inequality and discrimination, and exclusion. It also allows root cause analysis, and therefore, helps in identifying early-warning indicators (an element of conflict prevention) and long-term goals for peacebuilding programs, rather than short-term aims. The added value of a human-security plus approach is that it would utilize economic and social rights as a framework to address these issues by identifying rights violations, affording remedies, and providing legal protections against further violations based upon substantive provisions and the principles of equality, nondiscrimination, and special protections for vulnerable groups.

\section{OPERATIONALIZING THE HUMAN SECURITY PLUS APPROACH TO PEACEBUILDING}

This new hybrid "Human Security Plus" model can be effectively operationalized through three key mechanisms: (1) law and justiciability of norms, (2) policy and programming, and (3) advocacy and mobilization. This model 
requires an increasing role for the State - in respecting, protecting, and fulfilling economic and social rights, but also action by other actors involved in peacebuilding, including international organizations and nongovernmental organizations. The key is to operationalize this approach at all levels: grassroots, national, and international. As such, these integrated steps need to be taken as component parts of such a peacebuilding program:

The first mechanism requires putting in place normative measures and ensuring adequate enforcement and accountability mechanisms (O'Flaherty 2003 , 54). In terms of establishing legal provisions and related normative measures, economic and social rights must be codified as a priority, for example, through ratification of the ICESCR and other relevant international human rights law, and incorporation of these norms into the domestic legal system, either through constitutional or other national law. Enforcement and accountability measures include, inter alia, the establishment of a national human rights institution and adoption of international implementation mechanisms such as the Optional Protocol to the ICESCR.

Second, for these legal guarantees to be implemented effectively, policy and programmatic efforts are required. There is a need to determine the practical steps to be taken to operationalize these legal provisions - a functioning infrastructure with the capacity to deliver services to implement these rights is vital, as is institution building, including the provision of specialist institutions to protect and promote all human rights, including economic and social rights. To challenge the supremacy of civil and political rights within the current neoliberal agenda, a refocusing of priorities is required in terms of institution building and postconflict reconstruction. A human-security plus approach to institution building is not just concerned with the reestablishment of governance institutions of the transitional/postconflict state, but prioritizes the provision of "pro-poor policies in the emerging governance institutions" (Katorobol 2003, 12). It also prioritizes "direct financial and training assistance to enhance economic livelihood schemes, and poverty reduction projects at the grass roots of the communities" (Katorobol 2003).

Human-security plus institution building is not based upon political construction of competitive markets but rather embraces public ownership of essential services such as water delivery, health care, and education. This focus on ensuring human dignity contests the neoliberal "core prescriptions of macroeconomic stability, fiscal austerity and deregulation, with all their associated hardships" (Ahearne 2009, 35). Programming therefore includes taking a rights-based approach to development, reconstruction, and capacity building. A human-security plus approach to transitional or postconflict development uses economic and social rights as a tool with which to ensure that 
basic needs and services are prioritized as a challenge to free-market-based development, which may not benefit the existing marginalized or poor in the state. It prioritizes access to basic needs and services for individuals as well as addressing existing and underlying discrimination and inequalities, which may have been triggered or worsened during the conflict.

The final step required is advocacy and mobilization around economic and social rights and social justice from grassroots up and international organizations down.

\section{RECOMMENDATIONS}

From a broad human-security perspective, the benchmark is whether the state can exercise its primary functions of social protection and distributive justice, meeting welfare and educational needs and undertaking public service delivery (Newman 2011, 1750). A human-security plus approach to peacebuilding measures progress toward this benchmark by assessing a state's compliance with its duties to respect, protect, and fulfill the economic, social, and cultural rights of all. Economic and social rights indicators can be used for monitoring the realization of these rights and can highlight problems through use of disaggregated data and qualitative data such as testimonies based upon a violations approach (Cahill-Ripley 2011, 141; Chapman 1996).

Of course, development of a transitional or postconflict state will involve difficult discussions regarding budgets and recognition of the limitations of fragile states. The problem of meeting the immediate needs of the population in a society in transition from conflict to peace is often compounded by weak state infrastructure, lack of resources, and corruption. Although determining priorities will depend to a certain extent on the conflict in question, for every state it will be a question of balancing resources and considering existing capacities. However, it is imperative that where necessary, priority is given to building the institutional infrastructure and capacity to realize economic and social rights; for example, to realize the right to health, a functioning healthcare system is required. This will often entail rebuilding physical infrastructure that has been destroyed or damaged in conflict, as well as providing training to supply professional employees, all of which requires funding and resources, which could be in short supply.

Existing mechanisms and provisions within the international framework for economic and social rights can be useful; for example, the legal obligation to use maximum available resources and seek (and provide) international assistance under Article 2 of the ICESCR could be helpful in acquiring development assistance as well as in prioritizing resources. Rather than seeing 
international assistance as a way to achieve economic development, the focus becomes one of realization of economic and social rights as an integral part of the peacebuilding program. Moreover, a qualitative as well as quantitative approach should be taken to generating maximum available resources (Skogly $2012,405)$ and determining priorities for resource allocation, in these situations of resource scarcity. Skogly argues that much can be achieved without necessarily increasing financial means (2012).

Significantly, it may be more appropriate to tackle inequality and discrimination through more effective use and redistribution of existing resources, than through seeking further international assistance. (This is also significant in a transitional context as conflicts can be fueled by uneven distribution of resources). This approach directly confronts the neoliberal idea that international intervention by global financial institutions is always appropriate and illustrates how the human-security plus approach to peacebuilding can legitimize the redistribution of existing resources. Where IFIs are involved in peacebuilding, their role can be crucial in operationalizing a human-security plus approach. The legal obligations for IFIs to support the realization of economic and social rights in their operations is provided for through extraterritorial obligations, both indirect and direct (ETO Consortium 2014, 6-9). Thus, as these IFIs often drive the reconstruction process, it is essential that they refocus their policies and programs to give adequate consideration to economic, social, and cultural rights and human security. Consequently, this refocusing should include, as a priority, ceasing the conditionality on loans that results in negative impacts upon the realization of such rights in transitional and postconflict states.

In terms of programmatic efforts, the role of specialized international organizations, such as the UN agencies, requires consideration. These bodies have often been involved during the conflict, as peacekeepers, peacemakers, and negotiators and in relation to humanitarian assistance and development. However, it is also apparent that many of the international agencies involved in peacebuilding, including specialized organs of the United Nations, lack "a concrete approach to using their existing resources for the implementation of human rights" (Skogly 2012, 419). Schirch argues that an "agenda for coordinated action" is required to optimize the rights-based approach to peacebuilding (2006, 87-8). Consequently, in order to pursue a human-security plus approach to peacebuilding much more needs to be done to mainstream economic and social rights within the work of the relevant UN agencies, especially the UN Peacebuilding Commission and related bodies. An important element for achieving this "agenda for coordinated action" will be through advocacy and mobilization around economic and social rights at all levels. 
This is especially important when it comes to the idea of challenging the dominance and hegemony of the neoliberal agenda that permeates international and regional peacebuilding institutions (including elements of the UN).

At the international level, the recent review of the UN peacebuilding structures has been encouraging. The UN General Assembly and the UN Security Council concurrently adopted a resolution on April 27, 2016, "Review of the United Nations peacebuilding architecture," which recognizes that "development, peace and security, and human rights are interlinked and mutually reinforcing" (UN General Assembly 2016; UN Security Council 2016). The fact that the resolution was adopted by the UN General Assembly and the UN Security Council is significant, as it suggests a recognition and reaffirmation of policy at the highest level of the UN that had previously been lacking. Hitherto, these bodies have been cautious and limited in their consideration of the nexus between human rights, development, and peacebuilding, especially in regard to conflict prevention. Peacebuilding has been conceived of as a postconflict activity. However, the relevance and full scope of these areas of the UN's work have now been explicitly noted as matters for all member states and UN bodies.

Significantly, the resolution identifies the need for a new approach to peacebuilding: "Emphasizing the importance of a comprehensive approach to sustaining peace, particularly through the prevention of conflict and addressing its root causes...poverty eradication, social development, sustainable development" (UN General Assembly 2016, Preamble). However, it also echoes previous neoliberal priorities, including, "strengthening the rule of law at the international and national levels, and promoting sustained and sustainable economic growth...good governance, democracy, accountable institutions" (UN General Assembly 2016). Presently, the impact of the review of the peacebuilding architecture on the wider policy and practice of the UN and beyond remains to be seen, but a discussion is taking place as to how the peacebuilding agenda should change; and that is a positive step.

At the national level, states need to act in the interest of all citizens - not just the elites of the country. National Human Rights Institutions with a mandate to monitor and measure implementation of economic and social rights, including gathering disaggregated data, can assist the state in meeting its obligations and setting priorities for programming. However, the significance of having a strong civil society and grassroots human rights and social-justice movement should not be underestimated. Wills notes that the neoliberal system has co-opted much of civil society through "human face policies" such as poverty reduction strategies, whilst continuing to advocate and implement market-driven reforms $(2014,17)$. Consequently, if there is to be progress 
made in confronting or transforming the neoliberal system, then harnessing grassroots mobilization around economic and social rights as peacebuilding objectives is vital. As O'Connell notes, "Socio-economic rights, because their meaningful observance is fundamentally incompatible with the neo-liberal worldview, can and should be reclaimed to play an important role" in the struggle for an alternative system $(2011,554)$.

\section{CONCLUSION}

This chapter challenges the assumption that the neoliberal peacebuilding agenda is effective and contends that there is an inherent contradiction between the ideals of neoliberalism and the aim of building and sustaining peace. It questions the assumption that the neoliberal model of peacebuilding is necessarily the best model for promoting peace in transitional or postconflict situations. It argues for a reconsideration of the priorities for peacebuilding overall, and a move away from the neoliberal model encompassing only civil and political rights to a model that prioritizes human security and basic human needs through the realization of all human rights as indivisible. Moreover, it advocates for a special emphasis on economic and social rights to redress the imbalance caused by the deliberate omission of such rights from the neoliberal global system in the past.

The "Human Security Plus" model of peacebuilding promotes solidarity, encourages participation, prioritizes meeting basic human rights (and needs) using maximum available resources, and takes account of vulnerable and marginalized groups (Cahill-Ripley 2016). Where required, it helps to ensure basic human needs are met in states that are in a period of transition and postconflict through the establishment of legal and moral entitlements to economic and social rights, as well as reinforcing the indivisibility, protection, and promotion of all human rights. Of course, significant challenges remain, including the lack of political will to overhaul the existing system. Pressure needs to be put upon peacebuilding powers "to consider the fundamental questions about the extent to which the...neoliberal value system fosters...political and social instability" (Pugh 2004, 54). Economic and social rights can form the basis for this pressure for reform and can be effective in countering neoliberal ideology and existing peacebuilding policy, if they are interpreted in an expansive manner and if efforts to challenge neoliberalism are addressed at all operational levels: local, national, and international. A coordinated effort is required if economic and social rights are to effectively realize their inherent potential to support claims for social justice in transitional and postconflict contexts and thereby promote sustainable peace. 
While economic and social rights in their current form cannot successfully transform the entire neoliberal global system, they constitute a tool with which to contest neoliberalism that operates within the system itself. Despite the "disempowering political and economic system in which we live," we can strive for emancipatory peacebuilding (Thiessen 2011, 130), and economic and social rights constitute a reformist step in this transformation.

Significantly, the existing legal mechanisms for protection and promotion of economic and social rights can support transformative peacebuilding measures. They have a particularly important role to play in addressing structural violence and other issues traditionally excluded from peacebuilding, such as the exclusion of marginalized or disadvantaged groups. As Schirch notes, "The field of peacebuilding as a whole needs to create a long-term coordinated plan for addressing structural violence. The global community is lacking the will rather than the means to address issues of structural violence" (2006, 91). Ensuring the inclusion of economic and social rights within peacebuilding is one way to address human insecurity and structural violence within the current system, and can be enacted now. This is an ambitious aim and one that will attract opposition from those who benefit from the neoliberal system of governance. However, through the use of the human-security plus approach, the peacebuilding agenda can be reclaimed, making peacebuilding more effective and responsive to people's needs and making a significant contribution to delivering sustainable positive peace.

\section{References}

Ahearne, James. 2009. "Neoliberal Economic Policies and Post Conflict PeaceBuilding: A Help or Hindrance to Durable Peace?” POLIS Journal, Winter (2): $1-44$.

Arbour, Louise. 2007. "Economic and Social Justice for Societies in Transition." International Law and Politics 40(1): 1-27.

Avruch, Kevin and Christopher Mitchell. 2013. Conflict Resolution and Human NeedsLinking Theory and Practice. Oxford: Routledge.

Brett, Roddy and Lina Malagon. 2013. "Overcoming the Original Sin of the 'Original Condition:' How Reparations May Contribute to Emancipatory Peacebuilding." Human Rights Review 14: 257-71.

Burton, John. 1979. Deviance, Terrorism and War: The Process of Solving Unsolved Social and Political Problems. Oxford: Martin Robertson.

ed. 1990. Conflict: Human Needs Theory. London: Macmillan Press.

Cahill-Ripley, Amanda. 2011. The Human Right to Water and Its Application in the Occupied Palestinian Territories. Oxford: Routledge.

2014. "Foregrounding Socio-Economic Rights in Transitional Justice: Realising Justice for Violations of Economic and Social Rights." Netherlands Quarterly Human Rights 32(2): 183-213. 
2016. "Reclaiming the Peacebuilding Agenda: Economic and Social Rights as a Legal Framework for Building Positive Peace - a Human Security plus Approach to Peace-Building." Human Rights Law Review 16(2): 223-46.

Chapman, Audrey R. 1996. "A 'Violations Approach' for Monitoring the International Covenant on Economic, Social and Cultural Rights." Human Rights Quarterly 18(1): 23-66.

[The] Commission for Reception, Truth and Reconciliation in Timor-Leste. 2005a. Chega! The Report of the Commission for Reception, Truth and Reconciliation in Timor-Leste (CAVR) Part 2 - The Mandate of the Commission. Commission for Reception, Truth and Reconciliation October 31. See https://web.archive.org/ web/20131109002859/; www.cavr-timorleste.org/en/chegaReport.htm

2005b. Chega! The Report of the Commission for Reception, Truth and Reconciliation in Timor-Leste (CAVR) Executive Summary. Commission for Reception, Truth and Reconciliation October 31.

2005c. Chega! The Report of the Commission for Reception, Truth and Reconciliation in Timor-Leste (CAVR) Chapter 7.9 - Economic, Social and Cultural Rights. Commission for Reception, Truth and Reconciliation October 31.

2005 d. Chega! The Report of the Commission for Reception, Truth and Reconciliation in Timor-Leste (CAVR) Chapter 7.3 - Forced Displacement and Famine. Commission for Reception, Truth and Reconciliation October 31.

Estrada-Tanck, Dorothy. 2016. Human Security and Human Rights under International Law. Oxford: Hart.

ETO Consortium. 2014. ETOs in the Context of International Financial Institutions. Heidelberg: FIAN.

Galtung, Johan. 1969. "Violence, Peace, and Peace Research." Journal of Peace Research 6: 167-91.

1990. "International Development in Human Perspective." In Conflict: Human Needs Theory, edited by John Burton, 301-35. Basingstoke: Palgrave Macmillan.

Ho, Kathleen. 2007. “Structural Violence as a Human Rights Violation.” Essex Human Rights Review 4(2): 1-17.

International Council on Human Rights Policy. 2006. Negotiating Justice? Human Rights and Peace Agreements. Geneva: International Council on Human Rights Policy. Accessed August 14, 2017.www.ichrp.org/files/reports/22/128_report_en.pdf. International Covenant on Economic, Social and Cultural Rights (ICESCR). 1966. UNGA res. 2200A (XXI), UN Doc. A/6316.

Katorobol, James. 2003. "Democratic Institution Building in Post-Conflict Societies." UNDESA commissioned paper for Fifth International Conference on New or Restored Democracies, Ulaanbaatar, Mongolia, June 18-20, 2003, 1-28.

Kenya Human Rights Commission, The Kenyan Section Of The International Commission Of Jurists And International Centre For Policy And Conflict. 2010. Transitional Justice in Kenya - A Toolkit for Training and Engagement. Nairobi

Kenyan Truth, Justice and Reconciliation Commission. 2013. "The Final Report of the Truth, Justice \&Reconciliation Commission of Kenya Vol IV.” Truth Justice and Reconciliation Commission (TJRC), Kenya. Available at http://digitalcommons .law.seattleu.edu/tjrc/7

Lambourne, Wendy. 2004. "Post-Conflict Peacebuilding: Meeting Human Needs for Justice and Reconciliation.” Peace, Conflict and Development 4 (online) 
https://bradford.ac.uk/social-sciences/peace-conflict-and-development/issue-4/ PostConflictPeacebuilding.pdf

Laplante, Lisa. 2008. "Transitional Justice and Peace Building: Diagnosing and Addressing the Socioeconomic Roots of Violence through a Human Rights Framework.” The International Journal of Transitional Justice 2: 331-55.

Mac Ginty, Roger. 2010. "Hybrid Peace: The Interaction between Top-Down and Bottom-Up Peace.” Security Dialogue 41: 391-412.

Mapulanga-Hulston, Jackbeth. 2002. "Examining the Justiciability of Economic, Social and Cultural Rights." The International Journal of Human Rights 6(4): 29-48.

Newman, Edward. 2011. "A Human Security Peace-Building Agenda." Third World Quarterly 32(10): 1737-56.

O‘Connell, Paul. 2011. "The Death of Socio-Economic Rights.” Modern Law Review $74(4): 532-54$.

O'Flaherty, Michael. 2003. "Future Protection of Human Rights in Post- Conflict Societies: The Role of the United Nations." Human Rights Law Review 3: 53-76.

Paris, Roland. 1997. "Peacebuilding and the Limits of Liberal Internationalism." International Security 22: 54-89.

2010. "Saving Liberal Peacebuilding." Review of International Studies 36: 337-65.

Parlevliet, Michelle. 2018. "The Transformative Potential of Human Rights in Conflict Resolution." In Human Rights and Conflict Resolution: Bridging the Theoretical and Practical Divide, edited by Claudia Fuentes Julio and Paula Drummond. Oxford: Routledge.

Proclamation of Teheran. 1968. Final Act of the International Conference on Human Rights, Teheran, April 22 to May 13 1968. U.N. Doc. A/CONF. 32/41.

Pugh, Michael. 2004. "Peacekeeping and Critical Theory." International Peacekeeping 11(1): 39-58.

Richmond, Oliver P. 2007. "Emancipatory Forms of Human Security and Liberal Peacebuilding." International Journal 62(3): 458-77.

2009. "A Post-Liberal Peace: Eirenism and the Everyday." Review of International Studies 35(3): 557-80.

Richmond, Oliver, P. 2013. "Human Security and its Subjects." International Journal 68(1): 205-25.

2014. "The Impact of Socio-Economic Inequality on Peacebuilding and Statebuilding." Civil Wars, 16(4): 449-67.

Schmid, Evelyne. 2015. Taking Economic, Social and Cultural Rights Seriously in International Criminal Law. Cambridge: Cambridge University Press.

Schirch, Lisa. 2006. "Linking Human Rights and Conflict Transformation: A Peacebuilding Framework." In Human Rights and Conflict - Exploring the Links between Rights, Law and Peacebuilding, edited by Julie Mertus and Jeffrey Helsing, 63-95. Washington, DC: United States Institute of Peace Press.

Sharp, Dustin. 2012. "Addressing Economic Violence in Times of Transition: Toward a Positive-Peace Paradigm for Transitional Justice." Fordham International Law Journal 35: 780-97.

ed. 2014. Justice and Economic Violence in Transition. New York, NY: Springer Verlag.

Shue, Henry. 1996. Basic Rights: Subsistence, Affluence, and U.S. Foreign Policy. Princeton, NJ: Princeton University Press. Second Edition. 
Silva, Romesh and Patrick Ball. 2006. "The Profile of Human Rights Violations in Timor-Leste, 1974-1999." A Report by the Benetech Human Rights Data Analysis Group to the Commission on Reception, Truth and Reconciliation, February 9. Skaar, Elin and Eric Wiebelhaus-Brahm. 2013. "The Drivers of Transitional Justice: An Analytical Framework for Assessing the Role of Actors." Nordic Journal of Human Rights 31: 127-48.

Skogly, Sigrun. I. 2012. "The Requirement of Using the 'Maximum of Available Resources' for Human Rights Realisation: A Question of Quality as Well as Quantity?" Human Rights Law Review 12: 393-420.

UN General Assembly. 2015. Transforming Our World: The 2030 Agenda for Sustainable Development. UN Doc, A/RES/70/1. September 25.

Thiessen, Chuck. 2011. "Emancipatory Peacebuilding: Critical Responses to (Neo) Liberal Trends." In Critical Issues in Peace and Conflict Studies, edited by Thomas Matyok, Jessica Senehi, and Sean Byrne, 115-42. New York, NY: Lexington.

UN General Assembly. 2016. Review of the United Nations Peacebuilding Architecture, UN Doc. A/Res/70/262. April 27.

Universal Declaration of Human Rights (UDHR). 1948. UNGA res. 217A (III), UN Doc. A/810 at 71. December 10.

UN Security Council. 2016. Resolution 2282. UN Doc.S/RES/2282. April 27.

UN Trust Fund for Human Security. 2017. “Human Security Unit.” Accessed August 12. www.un.org/humansecurity/human-security-unit/human-security-approach.

Wills, Joe. 2014. “The World Turned Upside Down? Neo-Liberalism, Socioeconomic Rights and Hegemony." Leiden Journal of International Law 27(1): 11-35.

World Conference on Human Rights. 1993. Vienna Declaration and Programme of Action. UN Doc. A/CONF.157/23. June 25.

Ziegler, Jean, Christophe Golay, Claire Mahon, and Sally Ann Way, eds. 2011. The Fight for the Right to Food: Lessons Learned. Basingstoke: Palgrave Macmillan. 